9. Estraneo A, Moretta P, Loreto V, et al. Late recovery after traumatic, anoxic, or hemorrhagic long-lasting vegetative state. Neurology 2010;75:239-245.

\section{THE HISTORY OF CEREBRAL PET SCANNING: FROM PHYSIOLOGY TO CUTTING-EDGE TECHNOLOGY}

Tarun Singhal, Boston: The title of the article by Portnow et al. ${ }^{1}$ is not suitable because there is uneven coverage of the development of PET imaging devices and inadequate coverage of radiopharmaceuticals or their translational applications. There are some key conceptual and factual errors as well.

Contrary to the authors' contention, half-life of Carbon-14 is approximately 5,730 years, while halflife of Fluorine-18 is only 110 minutes: the latter's half- life is shorter-not longer-than the former's. Moreover, there was a need for an alternative agent for glucose imaging because Carbon-14 decays by beta particle formation and beta particles cannot penetrate the human body for image formation. Gamma rays formed after the positron decay of fluorine-18 and other positron emitters can penetrate the human body to enable emission imaging in living humans. Additionally, authors show an image of a "18 F-spiperone" scan but do not mention the pioneering studies by Wagner et al. ${ }^{2,3}$ on neuroreceptor imaging in the brain with $3-\mathrm{N}-\left[{ }^{11} \mathrm{C}\right]$ methylspiperone. Dr. Wagner is considered a forefather of nuclear medicine. ${ }^{4}$
Finally, PET can also be used for cerebellar and brainstem imaging — in addition to cerebral imaging — which is of relevance for several brain disorders.

Author Response: Michael Okun, Leah Portnow, David Vaillancourt, Gainesville, FL: We appreciate the comments by Dr. Singhal. Dr. Singhal is correct that we should have used the word "shorter half-life" instead of "longer half-life" when describing the half-life of FDG compared with $14 \mathrm{CDG}$. We are grateful that this error was noticed. We also agree that other elements of PET imaging including radiopharmaceuticals and the translational applications should have been included. In prior drafts, we had a more developed version consistent with these suggestions, but with the word count limits we were constrained to focus on key areas that were of particular interest to our research.

Editors' Note: A correction regarding the half-life of FDG appears on page 1275.

(c) 2013 American Academy of Neurology

1. Portnow LH, Vaillancourt DE, Okun MS. The history of cerebral PET scanning: from physiology to cutting-edge technology. Neurology 2013;80:952-956.

2. Wagner HN Jr, Burns HD, Dannals RF, et al. Imaging dopamine receptors in the human brain by positron tomography. Science 1983;221:1264-1266.

3. Jones T, Rabiner EA. The development, past achievements, and future directions of brain PET. J Cereb Blood Flow Metab 2012;32:1426-1454.

4. Society of Nuclear Medicine and Molecular Imaging member news, September 27, 2012. Available at: http://www.snm.org/ index.cfm?PageID=12082. Accessed July 31, 2013.

\title{
CORRECTION
}

\section{The history of cerebral PET scanning: From physiology to cutting-edge technology}

In the Historical Neurology article "The history of cerebral PET scanning: From physiology to cutting-edge technology" by L.H. Portnow et al. (Neurology ${ }^{\circledR}$ 2013;80:952-956), there is an error on page 954. When describing the half-life of FDG compared with $\left[{ }^{14} \mathrm{C}\right] \mathrm{DG}$, the authors should have used "shorter half-life" instead of "longer half-life." The authors regret the error. 


\section{Neurology}

\section{The history of cerebral PET scanning: From physiology to cutting-edge technology}

Tarun Singhal, Michael Okun, Leah Portnow, et al.

Neurology 2013;81;1275

DOI 10.1212/01.wnl.0000435802.68308.a1

This information is current as of September 30, 2013

Updated Information \& Services

References

Permissions \& Licensing

Reprints including high resolution figures, can be found at: http://n.neurology.org/content/81/14/1275.1.full

This article cites 3 articles, 2 of which you can access for free at: http://n.neurology.org/content/81/14/1275.1.full\#ref-list-1

Information about reproducing this article in parts (figures,tables) or in its entirety can be found online at:

http://www.neurology.org/about/about_the_journal\#permissions

Information about ordering reprints can be found online:

http://n.neurology.org/subscribers/advertise

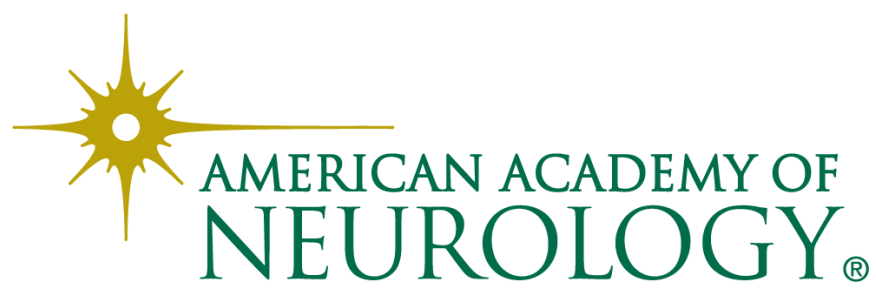

